\title{
Bacteriocine typing of Klebsiella spp
}

\author{
FELICITY A. HALL1 \\ From the Hospital Infection Research Laboratory, Summerfield Hospital, Birmingham 18
}

SYNOPSIS One hundred and six strains of Klebsiella spp were examined for their ability to produce bacteriocine. Nine of these, together with one strain from the National Collection of Type Cultureso were selected and used to type Klebsiella strains from various sources. Strains were typed by testings their sensitivity to bacteriocines produced by the standard set of 10 strains. Eight hundred strains were tested and $77 \%$ of these were typable and could be divided into a relatively large number op groups, some of which occurred consistently more frequently than others.

This simple method has been shown to have some value in epidemiological investigations.

In recent years Gram-negative bacilli have been reported to cause a larger proportion of severe infections than formerly (Finland, 1960; Watt and Okubadejo, 1967). Following improvements in the control of infection by Pseudomonas aeruginosa, other Gram-negative organisms, including Klebsiella spp., have come into greater prominence as agents of hospital infection in patients with diminished resistance (eg, Ørskov, 1952 and 1954; Weil, Ramchand, and Arias, 1966; Cason, Jackson, Lowbury, and Ricketts, 1966; Steinhauer, Eickhoff, Kislak, and Finland, 1966).

Bacteriocine typing has proved valuable in studies on the epidemiology of infections with Shigella sonnei, Ps. aeruginosa, and some other species. Bacteriocines of Klebsiella spp. have been described by Hamon and Péron (1963), and the development of bacteriocine typing for this group of organisms is reported by Slopek and Maresz-Babczyszyn (1967).

In this paper I report an attempt to produce a scheme for typing strains of Klebsiella by determining the pattern of bacteriocine producer strains of Klebsiella spp. to which the unknown strains were sensitive. The reliability and practicability of such a scheme is discussed.

\section{Materials and Methods}

SOURCES OF STRAINS

Over the past two years, 800 strains of Klebsiella have been examined. These were obtained from a number of hospitals throughout the country and 'Present address: Department of Bacteriology, Wright-Fleming Institute, Paddington, W2.

Received for publication 10 February 1971. also from the National Collection of Type Cultures The strains were isolated mainly from urine, sputum faeces, wound swabs, high vaginal swabs, burns, and other clinical specimens, and also from environ? mental sources, eg, nail brushes, hand creams, toilet seats, and from infant feeds in a hospital millo kitchen. One hundred and thirty two of the strains referred to later as the 'epidemic strains', were isolated from a single hospital during a recent outbrealo of infection.

IDENTIFICATION OF SPECIES

The first 106 strains, a miscellaneous collection fron? various hospital sources, were identified according te. the methods described by Cowan and Steel (1965) They were all tested for ability to ferment inosito? adonitol, glucose, lactose, and dulcitol, for motility and for their methyl red and Voges-Proskauein reaction and utilization of citrate. Those subses quently found to produce a bacteriocine-like sub stance were also tested for decarboxylase reactions? oxidation of gluconate, and utilization of malonateo

After selection of a number of bacteriocine pro ducers to be used in the typing scheme, strain received as Klebsiella spp. which showed typical colonial appearance were examined for motility to exclude strains of Enterobacter. No further species identification was attempted except in certair circumstances, such as the investigations into the contamination of infant feeds in a Milton milB kitchen (Ayliffe, Collins, and Pettit, 1970).

ANTIBIOTIC SENSITIVITY TESTS Nutrient agar plates were flooded with broth culture grown in a shaking water bath at $37^{\circ} \mathrm{C}$ for two t 
two and a half hours. Mast rings and antibiotic discs were applied and the sensitivity of strains to ampicillin, chloramphenicol, colistin, kanamycin, nalidixic acid, nitrofurantoin, streptomycin, tetracycline, cephaloridine, and, with more recent isolates, to carbenicillin, was recorded after 24 hours' incubation at $37^{\circ} \mathrm{C}$.

\section{ISOLATION OF BACTERIOCINE PRODUCERS}

The initial collection of 106 hospital strains from miscellaneous sources were tested for production of, and sensitivity to, bacteriocine by the following method. Using growth from single colony isolates on a 'spot' plate, nutrient agar plates were inoculated with two replicate streaks of the same culture per plate. The plates were incubated at $37^{\circ} \mathrm{C}$ for 24 hours and the streaks of bacterial growth removed by scraping with the edge of glass microscope slides. Any remaining bacteria were killed by exposing the plates to chloroform for 10 to 15 minutes. All traces of chloroform were dispelled by leaving the plates open to the air for a further 15 to 20 minutes. Plates were then seeded at right angles to the original growth lines with loopfuls of broth cultures of the same set of 106 strains of Klebsiella spp which had been grown for two to two and a half hours in a shaking water bath at $37^{\circ} \mathrm{C}$. Sensitivity patterns were recorded after overnight incubation at $30^{\circ} \mathrm{C}$.

\section{BACTERIOCINE TYPING}

This was carried out as for the detection of bacteriocine producers, two parallel streaks of the same producer strain being inoculated on each plate. Cultures to be tested for sensitivity to the bacteriocines were grown in nutrient broth in a shaking water bath at $37^{\circ} \mathrm{C}$ for two to two and a half hours before being streaked at right angles to the original growth lines of the 10 producers selected for use in the typing scheme.
PHAGE TYPING

A proportion of the strains of Klebsiella spp which had been bacteriocine typed by the author were sent to the Public Health Laboratory, Colindale, London, for phage typing using their own set of Klebsiella phages.

\section{Results}

Species identification of the 105 miscellaneous strains from hospital patients, from which the bacteriocine producers were subsequently selected for the typing scheme, showed that approximately $79 \%$ were $K$. aerogenes, $18 \% \mathrm{~K}$. pneumoniae, and $3 \%$ $K$. edwardsii var edwardsii. Klebsiella strains from other sources which were species-identified were mainly $K$. aerogenes $(99 \%)$.

\section{ANTIBIOTIC SENSITIVITY}

Table I shows the percentage distribution of antibiotic resistance among 106 miscellaneous strains used for selection of bacteriocine producers, and among Klebsiella strains from varying sources which were also tested. A high percentage of strains from all sources were resistant to ampicillin and many were also resistant to chloramphenicol, streptomycin, tetracycline, and cephaloridine. The percentages of strains tested which were resistant to kanamycin, colistin, nalidixic acid, and nitrofurantoin were low, with the exception of the hospital epidemic strains; $84 \%$ of these showed resistance to kanamycin.

\section{ISOLATION OF BACTERIOCINE PRODUCERS}

Approximately $40 \%$ of the 106 miscellaneous strains tested produced bacteriocines, which were given numbers corresponding to the culture numbers of the strains producing them. The patterns of sensitivity to these bacteriocines varied considerably among the strains tested. The original growth streak of the

\begin{tabular}{|c|c|c|c|c|c|c|c|c|c|c|c|}
\hline \multirow[t]{2}{*}{ Source } & \multirow{2}{*}{$\begin{array}{l}\text { Number } \\
\text { of } \\
\text { Strains }\end{array}$} & \multicolumn{10}{|c|}{ Percentage of Strains Resistant to } \\
\hline & & $A p$ & $C$ & Co & $\boldsymbol{K}$ & $N a$ & $\mathrm{Ni}$ & $S$ & $T$ & $C p$ & $P y$ \\
\hline $\begin{array}{l}\text { Miscellaneous strains' } \\
\text { Urine } \\
\text { Sputum } \\
\text { Wound swabs } \\
\text { Vaginal swabs } \\
\text { Burns } \\
\text { Faeces (babies) } \\
\text { Infant feeds } \\
\text { Hospital epidemic }\end{array}$ & $\begin{array}{r}106 \\
110 \\
49 \\
45 \\
21 \\
29 \\
49 \\
36 \\
132\end{array}$ & $\begin{array}{r}85 \\
86 \\
96 \\
62 \\
100 \\
66 \\
96 \\
90 \\
98\end{array}$ & $\begin{array}{r}35 \\
10 \\
17 \\
12 \\
0 \\
41 \\
12 \\
0 \\
91\end{array}$ & $\begin{array}{r}10 \\
0 \\
12 \\
18 \\
7 \\
0 \\
4 \\
0 \\
0\end{array}$ & $\begin{array}{r}15 \\
7 \\
0 \\
0 \\
0 \\
4 \\
4 \\
3 \\
84\end{array}$ & $\begin{array}{l}9 \\
3 \\
0 \\
0 \\
0 \\
0 \\
0 \\
0 \\
9\end{array}$ & $\begin{array}{r}54 \\
14 \\
0 \\
0 \\
0 \\
34 \\
38 \\
0 \\
7\end{array}$ & $\begin{array}{r}51 \\
18 \\
46 \\
19 \\
11 \\
31 \\
14 \\
0 \\
84\end{array}$ & $\begin{array}{r}43 \\
22 \\
44 \\
37 \\
14 \\
52 \\
10 \\
3 \\
76\end{array}$ & $\begin{array}{r}21 \\
8 \\
55 \\
50 \\
46 \\
7 \\
14 \\
27 \\
24\end{array}$ & $\begin{array}{l}1 \\
1 \\
1 \\
1 \\
1 \\
1 \\
49 \\
0 \\
1\end{array}$ \\
\hline
\end{tabular}

Table I Antibiotic resistance of strains of Klebsiella isolated from different sources

${ }^{1}$ Strains from which Klebsiella bacteriocine producers were selected. $\mathrm{Ap}=$ ampicillin, $\mathrm{C}=$ chloramphenicol, Co $=$ colistin, $\mathrm{K}=\mathbf{k a n a m y c i n}$, $\mathrm{Na}=$ nalidixic acid, $\mathrm{Ni}=$ nitrofurantoin, $\mathrm{S}=$ streptomycin, $\mathrm{T}=$ tetracycline, $\mathrm{Cp}=$ cephaloridine, Py $=$ carbenicilin 
producer was about $0.6 \mathrm{~mm}$ wide. In some cases area of total lysis extended across this and up to about $1.5 \mathrm{~cm}$ on either side of it, whereas in others reduction of growth across the producer streak was barely discernible. Occasionally a few resistant colonies were present in the area of complete lysis. Strains were recorded as sensitive when areas of total lysis occurred, incompletely sensitive when resistant colonies were present in the area of total lysis, or when there was a clearly definable inhibition of growth, but no complete area of lysis, and very weakly sensitive when reduction of growth across the producer streak was barely discernible.

Of the 42 strains which produced bacteriocine, seven were selected for use in the typing scheme. Producer strains were discarded, when the bacteriocine they produced caused very slight inhibition of growth of the strains tested for sensitivity to them or were indistinguishable from other bacteriocines already selected for the typing set, as shown by the pattern of strains sensitive to them. The 26 strains remaining after these exclusions were phage typed. Six different phage types were found to be present; one strain of each phage type which showed a bacteriocine-production pattern distinct from that of the others was therefore kept for incorporation into the typing scheme. Three other strains which had not been phage typed, but to which a few strains were very sensitive, and a non-phage-typable strain received from the National Collection of Type Cultures, were also included.

Table II shows the source, antibiotic resistance pattern, bacteriocine type, phage type, and species identification of these 10 strains selected for use in the bacteriocine typing scheme.

\section{BACTERIOCINE TYPING}

Six hundred and twenty four strains of Klebsiella spp from hospital patients and from the environment were typed. As with the isolation of the producers, sensitivity, incomplete sensitivity, and very weak $\stackrel{\text { 을 }}{\vec{F}}$ sensitivity were recorded.

Fifty distinct patterns of sensitivity to the bacteriocines were recorded, but most of the typable strains? belonged to one of 16 typing patterns. Table III shows the percentage distribution of these patterns $\vec{T}$ among strains of Klebsiella isolated from different $\odot$ sources. The percentages of non-typable strains and $\%$ of other types are also shown.

In the case of the hospital epidemic strains, a high percentage of non-typable strains was found. How- $\vec{\omega}$ ever, as these were all shown by biochemical tests to be $K$. aerogenes, and to have similar antibiotic resis-o tance patterns to each other but different from most other strains tested, it is possible that they wereoo identical in type. Negative results were obtained $\mathbb{}$ when they were tested against each other and with $a^{N}$ number of other strains of typed Klebsiella for bacteriocine production and sensitivity.

In assigning strains to a particular type all degreeso of sensitivity are taken into consideration; however, if there are 'sensitive' and 'incompletely sensitive' reactions corresponding to one of the more frequently occurring types, other very weakly sensitive reactions are ignored. The 24 types not enumerated. in Table III are mainly based on weakly sensitive reactions.

Experiments in which replicate typing was carried out on different days showed that sensitive and incom pletely sensitive reactions are usually reproducible but weakly sensitive reactions may be variable.

In other experiments, however, in which 10 single colonies were picked from a number of strains of different bacteriocine type, it was found that they all typed to give the same pattern as that of the strain from which they were isolated.

APPLICATIONS OF BACTERIOCINE TYPING The bacteriocine typing scheme described above haS been found useful in several investigations of hospitaß

\begin{tabular}{|c|c|c|c|c|c|}
\hline Klebsiella Strain & Source & Antibiotic Resistance & Bacteriocine Type & Phage Type & Species \\
\hline $\begin{array}{r}3 \\
4 \\
5 \\
7 \\
23 \\
24 \\
27 \\
30 \\
77 \\
9137\end{array}$ & $\begin{array}{l}\text { Eye swab } \\
\text { Wound swab } \\
\text { Blood culture } \\
\text { Urine } \\
\text { Sputum } \\
\text { Urine } \\
\text { Sputum } \\
\text { Urine } \\
\text { Vaginal swab } \\
\text { NCTC }\end{array}$ & $\begin{array}{l}\text { (S) } \\
\text { ApTCp } \\
\text { ApCKTPy } \\
\text { ApCSPy } \\
\text { ApSPy } \\
\text { ApCSPy } \\
\text { Ap } \\
\text { ApPy } \\
\text { ApCKTCpPy } \\
\text { ApNiSPy }\end{array}$ & $\begin{array}{l}4 / 7 / 23 \\
3 \\
3 \\
3 \\
3 \\
3 / 27 / 9137 \\
3 / 4 / 7 / 23 \\
3 \\
3 \\
4 / 7 / 23 / 27\end{array}$ & $\begin{array}{l}1 / 5 / 10 / 16 / 10 \\
2 / 16 / 17 \\
\text { ND } \\
2 / 16 \\
2 \\
\text { ND } \\
2 / 7 \\
2 / 3 / 17 \\
\text { ND } \\
\text { NT }\end{array}$ & $\begin{array}{l}\text { Aerogenes } \\
\text { Edwardsii var edwardsii } \\
\text { Aerogenes } \\
\text { Aerogenes } \\
\text { Pneumoniae } \\
\text { Edwardsii var edwardsii } \\
\text { Aerogenes } \\
\text { Aerogenes } \\
\text { Aerogenes } \\
\text { Species }\end{array}$ \\
\hline
\end{tabular}

Table II Klebsiella bacteriocine producers selected for use in the typing scheme

NCTC = National Collection of Type Cultures, $(\mathbf{S})=$ sensitive to all antibiotics tested, $\mathbf{A p}=$ ampicillin, $\mathbf{C}=$ chloramphenicol, $\mathbf{K}=\mathbf{k a n a m y c i}$ $\mathrm{Ni}=$ nitrofurantoin, $\mathrm{S}=$ streptomycin, $\mathrm{T}=$ tetracycline, $\mathrm{Cp}=$ cephaloridine, $\mathrm{Py}=$ carbenicillin, $\mathrm{ND}=$ not typed. $\mathrm{NT}=$ not typable 


\begin{tabular}{|c|c|c|c|c|c|c|c|c|c|c|c|}
\hline \multirow{2}{*}{$\begin{array}{l}\text { Bacteriocine } \\
\text { Type }\end{array}$} & \multicolumn{11}{|c|}{ Percentage of Strains from Different Sources } \\
\hline & $\begin{array}{l}\text { Miscellaneous } \\
\text { Strains }{ }^{1}\end{array}$ & Urine & Sputum & $\begin{array}{l}\text { Wound } \\
\text { Swabs }\end{array}$ & $\begin{array}{l}\text { Vaginal } \\
\text { Swabs }\end{array}$ & $\begin{array}{l}\text { Faeces } \\
\text { (adult) }\end{array}$ & $\begin{array}{l}\text { Faeces } \\
\text { (babies) }\end{array}$ & Burns & Epidemic & $\begin{array}{l}\text { Infant } \\
\text { Feeds }\end{array}$ & Environment \\
\hline 3 & 53 & 24 & 37 & 27 & 43 & 67 & 18 & 50 & 42 & 19 & 31 \\
\hline $3 / 27$ & 7 & 15 & 6 & 7 & 10 & 0 & 12 & 12 & 1 & 4 & 3 \\
\hline $3 / 4 / 7 / 27$ & 0 & 0 & 0 & 0 & 0 & 0 & 2 & 0 & 0 & 58 & 0 \\
\hline 27 & 2 & 3 & 4 & 9 & 5 & $\mathbf{0}$ & 29 & 1 & 2 & 0 & 2 \\
\hline $3 / 4 / 7 / 23 / 24 / 27$ & 0 & 4 & 4 & 0 & 0 & 11 & 0 & 0 & 0 & 0 & 29 \\
\hline $4 / 7 / 23 / 24 / 27$ & 0 & 3 & 8 & 13 & 0 & 0 & $\mathbf{0}$ & 8 & 0 & 0 & 8 \\
\hline $3 / 27 / 9137$ & 1 & 11 & 2 & 9 & 0 & 0 & 0 & 1 & 0 & 0 & 0 \\
\hline $3 / 9137$ & 0 & 5 & 2 & 0 & 0 & 0 & 14 & 0 & 1 & 0 & 0 \\
\hline $3 / 5 / 30 / 77$ & 1 & 1 & 4 & 2 & 5 & 0 & 0 & 4 & 0 & 0 & 2 \\
\hline 9137 & 0 & 0 & 4 & 0 & 10 & 0 & 2 & 0 & 0 & 0 & 3 \\
\hline $3 / 27 / 77$ & 0 & 2 & 0 & 0 & 0 & 11 & 0 & 1 & 0 & 0 & 2 \\
\hline $4 / 7 / 23 / 24$ & 0 & 2 & 2 & 0 & 5 & 0 & 0 & 1 & 0 & 0 & 6 \\
\hline $4 / 7$ & 0 & 0 & 0 & 0 & 0 & 0 & 6 & 0 & 1 & 8 & 0 \\
\hline 7 & 1 & 3 & 2 & 2 & 0 & 0 & 0 & 0 & 0 & 0 & 0 \\
\hline $5 / 30 / 77$ & 0 & 0 & 0 & 2 & 0 & 0 & 4 & 0 & 0 & 0 & 0 \\
\hline $3 / 4 / 5 / 30$ & 0 & 0 & 0 & 2 & 0 & 0 & 0 & 4 & 0 & 0 & 0 \\
\hline NT & 22 & 15 & 20 & 13 & 22 & 0 & 8 & 15 & 46 & 11 & 13 \\
\hline Other types & 13 & 12 & 5 & 4 & 0 & 11 & 5 & 3 & 7 & 0 & 1 \\
\hline strains typed & 106 & 110 & 49 & 45 & 21 & 9 & 49 & 108 & 132 & 36 & 65 \\
\hline
\end{tabular}

Table III Bacteriocine types of 630 strains of Klebsiella isolated from different sources

'Strains from which Klebsiella bacteriocine producers were selected

infection. During a recent hospital survey Klebsiella spp were found in jars of hand cream on a number of wards. These were typed and organisms of the same type, $3 / 4 / 7 / 23 / 24 / 27$, were ultimately isolated from the main supply jar in the hospital dispensary. Strains of the same bacteriocine type were isolated also from opened and unopened bottles of a commercially produced hand washing preparation in use at a number of different hospitals, showing that this contamination was probably introduced with supplies of the hand cream.

Another situation in which the scheme has been usefully applied was in investigations into contamination of infant feeds in a hospital milk kitchen. Strains of Klebsiella of bacteriocine types $4 / 7$ and $3 / 4 / 7 / 27$ were shown to be present in the infant feeds and in the faeces of the babies receiving the feeds (Ayliffe et al, 1970). Follow-up studies on the faeces of neonates from other hospitals indicated that an endemic strain of Klebsiella was present in the nurseries of three hospitals and each strain was of a different bacteriocine type. In one hospital bacteriocine types 3 or $3 / 27$ were isolated from the faeces of $14 / 26$ babies, in the second hospital types $3 / 9137$ were isolated from 9/20 babies, and in the third hospital bacteriocine type 27 was isolated from $16 / 31$ babies. In the latter two hospitals no Klebsiella spp were isolated from the infant feeds.

In another hospital bacteriocine typing also showed the presence of more than one type of Klebsiella causing a recent hospital epidemic when most of the strains isolated had previously been found to be nonphage-typable. As can be seen from Table III, $42 \%$ of these strains were typed as bacteriocine type 3 , small proportion ( $₹ 2 \%$ ) of Klebsiella isolates from patients in the outbreak were of types $3 / 27,27$, $3 / 9137$, and $4 / 7$, and five further closely related types not enumerated in Table III. There were also many strains that could not be typed by the bacteriocine typing method but, as has been mentioned previously, these may have belonged to the same type since they were all $K$. aerogenes and had similar antibiotic resistance patterns.

Preliminary studies on a few faecal strains of Klebsiella isolated from members of the general public show that these strains, like the Klebsiellas isolated from patients and other sources in hospital, were most frequently of bacteriocine types 3 and 27. Two other infrequently found bacteriocine typing patterns, 3/30/77 and 27/9137 (not listed in Table III), were shown by two of the strains typed. Insufficient evidence is as yet available to say whether these findings are representative of the distribution of bacteriocine typing patterns among Klebsiellas carried by members of the general public.

\section{Discussion}

The typing scheme described above shows the divisions of Klebsiella species into many types. The predominance of bacteriocine type 3 amongst strains from all sources is a disadvantage, but it is possible that further investigations into the bacteriocineproducing abilities of other strains might lead to the isolation of further producers to subdivide this group. Apart from a number of the epidemic strains, 
phage typing has been carried out on 240 of the strains which have been bacteriocine typed, and $74 \%$ of these were phage-typable. However, the proportion of my cultures that were phage-typable was considerably higher than the proportion typable in a larger series of strains examined by Dr E. A. Asheshov. Of the $12 \%$ of non-bacteriocine-typable strains, $52 \%$ were phage typable and of the $26 \%$ non-phagetypable strains $78 \%$ were typable by the bacteriocine method. Only $5.8 \%$ of the strains were not typable by both methods.

Besides distinguishing between some of the strains that could not be typed by the bacteriocine method, phage typing seems also to provide a means whereby bacteriocine type 3 may be divided to some extent. However, a high proportion (48\%) of these strains had the same phage pattern and this pattern was not confined to bacteriocine type 3 strains. Eight per cent of type 3 strains were not typable by phage and the the remainder showed 17 different, though fairly similar, phage patterns.

A further limitation of the bacteriocine typing scheme as it stands arises from the large number of very weakly sensitive reactions. Phage typing has proved helpful in confirming the similarity or difference between strains showing such reactions, but it is hoped that a way to improve the sensitivity of the bacteriocine typing method will be found. Sterile filtrates of bacteriocine from organisms treated with ultraviolet irradiation were spotted onto plates which had been flooded with cultures of the organisms under test. Sensitivity to the bacteriocines was more easily recognizable in some instances, but more often than not, and particularly when the organisms under test were very mucoid, tests made in this way could not be read and the streak method was finally chosen for use as it gave better results. Other possibilities for improved reactions are by incubation of the producer streak at a different temperature, or by the use of bacteriocines after mitomycin C extraction (Farmer and Herman, 1969). Further studies on these lines are planned.

As a routine procedure for the assessment of epidemiological relationships between strains the system on its present form is clearly deficient. Strains of similar bacteriocine type were shown to be found in all types of clinical specimen (urine, sputum, wound swabs, high vaginal swabs) and i⿱ the environment, no particular type being confinet to any one source, and no particular strain was found to predominate in any one ward. On the other hand the scheme has proved useful in the specific instances mentioned (investigation of cons taminated hand cream, of hand washing prepap ations, of contamination in a hospital milk kitcherw and of a recent hospital outbreak of Klebsielly infection). It is thus concluded that bacteriocine typing by the method described above can in spite ot its present limitations be useful for epidemiologicas studies.

I wish to thank Dr E. A. Asheshov of the Centrab Public Health Laboratory, Colindale, for phage typing a number of the strains of Klebsiella $\mathrm{spp}_{\delta}^{0}$ Dr G. A. J. Ayliffe and Dr E. J. L. Lowbury fơ their advice, and the many people who supplied me with cultures.

\section{References}

Ayliffe, G. A. J., Collins, B. J., and Pet tit, F. A. (1970). Contamination of infant feeds in a Milton milk kitchen. Lancet, 1, 559-560. Cason, J. S., Jackson, D. M., Lowbury, E. J. L., and Ricket ts, C. R (1966). Antiseptic and aseptic prophylaxis for burns: use of silver nitrate and of isolators. Brit. med. J., 2, 1288-1294.

Cowan, S. T., and Steel, K. J. (1965). Manual for the Identification कf Medical Bacteria. Cambridge University Press, London.

Farmer, J. J. III, and Herman, L. G. (1969). Epidemiological finge? printing of Pseudomonas aeruginosa by the production of anf sensitivity to pyocin and bacteriophage. J. appl. Microbiol., 16 760-765.

Finland, M. (1960). Treatment of pneumonia and other serious infections. New Engl. J. Med., 263, 207-221.

Hamon, Y., and Péron, Y. (1963). Individualisation de quelque nouvelles familles d'entérobactériocines. C.R. Acad. Sct. Paris. 257, 309-311.

Ørskov, I. (1952). Nosocomial infections with Klebsiella in lesions off the urinary tract. Acta path. microbiol. Scand., Suppl., 93. 259-271.

Ørskov, I. (1954). Nosocomial infections with Klebsiella in lesions $\frac{\Omega}{\phi \Phi}$ the urinary tract. Acta path. microbiol. Scand. Suppl., 35 194-204.

Slopek, S., and Maresz-Babczyszyn, J. (1967). A working scheme fox typing Klebsiella bacilli by means of pneumocins. Arch Immunol. Therap. Exp., 15, 525-529.

Steinhauer, B. W., Eickhoff, T. C., Kislak, J. W., and Finland, M (1966). The Klebsiella-Enterobacter-Serratia division clinica and epidemiological characteristics. Ann. intern. Med., 65 1180-1194.

Watt, P. J., and Okubadejo, O. A. (1967). Changes in incidence and aetiology of bacteraemia arising in hospital practice. Brin med. $J ., 1,210-211$.

Weil, A. J., Ramchand, S., and Arias, M. E. (1966). Nosocomigu infection with Klebsiella Type 25. New. Engl. J. Med., 275, 17-22. 